\title{
A bio-economic evaluation of the potential for establishing a commercial fishery on two newly developed stocks: The Ionian red shrimp fishery
}

\author{
JORDI GUILLEN ${ }^{1,2,3}$, FRANCESC MAYNOU ${ }^{4}$, CHRISTOS FLOROS ${ }^{5}$, \\ DAVID SAMPSON $^{2,6}$, ALEXIS CONIDES $^{7}$ and KOSTAS KAPIRIS ${ }^{7}$ \\ ${ }^{1}$ Ifremer, UMR AMURE, Unité d'Economie Maritime, BP 70, F-29280 Plouzané Cedex, France. \\ E-mail: jordi.guillen.garcia@ifremer.fr \\ ${ }^{2}$ Joint Research Centre - European Commission, IPSC, Maritime Affairs Unit, Via E. Fermi 2749, 21027 Ispra, Italy. \\ ${ }^{3}$ Universitat de Barcelona, Facultat d’Economia i Empresa, Av. Diagonal 690, 08034 Barcelona, Spain. \\ ${ }^{4}$ Institut de Ciències del Mar (CSIC), Psg. Marítim de la Barceloneta 37-49, 08003 Barcelona, Spain. \\ ${ }^{5}$ Department of Economics, CEMARE, University of Portsmouth, Portsmouth, PO1 3DE, United Kingdom. \\ ${ }^{6}$ Oregon State University, Coastal Oregon Marine Experiment Station and Department of Fisheries and Wildlife, \\ Hatfield Marine Science Centre, Newport, Oregon 97365, USA. \\ ${ }^{7}$ Hellenic Centre for Marine Research, Institute for Marine Biological Resources, 46,7 km Athens-Sounion Avenue,
} 19013 Anavyssos, Greece.

SUMMARY: It has recently been shown that two deep-water red shrimp species (Aristeus antennatus and Aristaeomorpha foliacea) have the potential to support a viable fishery in the Greek Ionian Sea (eastern Mediterranean). In this article, we investigate (i) the evolution that this newly developed trawl shrimp fishery may undergo when subjected to different management measures, and (ii) the most suitable extraction rates considering the uncertainties about the resource. We further analyse the effects that potential future fuel price increases and changes in the market may have on the fishery. Forecasting the biological and economic consequences of management actions, as well as the effects of market changes on inputs and outputs before they are applied, may help managers select the most suitable management options. We approach the problem by means of bio-economic simulation analysis. The results of this study show that fishing effort can increase by $50-100 \%$, increasing the fleet's profitability without jeopardizing the sustainability of the fishery.

Keywords: bio-economic modelling, market development, fuel price, newly developed stocks, Ionian Sea, red shrimps.

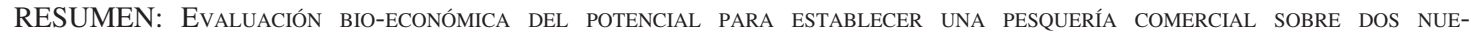
VOS STOCKS: LA PESQUERÍA DE GAMBAS ROJAS DEL JÓNICO - Recientemente se ha demostrado que dos especies de gambas rojas de profundidad (Aristeus antennatus and Aristaeomorpha foliacea) tienen el potencial de sostener una pesquería viable en el mar Jónico griego (Mediterráneo oriental). En este trabajo investigamos i) la evolución que esta nueva pesquería de gambas puede tener ante distintas medidas de gestión, y ii) cuáles serían las tasas de extracción del recurso más adecuadas teniendo en cuenta la incertidumbre sobre el recurso. Además analizamos los efectos que puedan tener sobre la pesquería el aumento del precio del combustible y cambios en el precio de mercado. La proyección de las consecuencias biológicas y económicas de las acciones de gestión, así como los efectos de cambios en el mercado sobre las entradas y salidas antes de ser aplicadas puede ayudar a los gestores a seleccionar las opciones de gestión más adecuadas. Proporcionamos una aproximación al modelo mediante análisis bio-económico de simulación. Los resultados de este estudio muestran que el esfuerzo de pesca puede aumentar en un 50 a $100 \%$, aumentando la rentabilidad de la flota, sin comprometer negativamente la sostenibilidad de la pesquería.

Palabras clave: modelización bioeconómica, desarrollo de mercados, precio del combustible, stocks nuevos, mar Jónico, gambas rojas. 


\section{INTRODUCTION}

Stocks of two species of deep-water shrimps, the blue-and-red shrimp and the giant red shrimp (Aristeus antennatus and Aristaeomorpha foliacea, family Aristeidae), comprise valuable resources of Mediterranean fisheries (Carlucci et al. 2006, Mytilineou et al. 2006). Red shrimp stocks have been exploited commercially since the 1930s in the western Mediterranean basin (Relini and Orsi-Relini 1987, Bas 2006), while new deep fishing grounds have been discovered in recent decades, especially in the eastern Mediterranean (Bas 2006). Declared landings of red shrimps in the entire Mediterranean amounted to $5000 \mathrm{t}$ in 2008 (FAOGFCM 2011), but their economic importance is higher because of the high market prices for red shrimps (from $10 € / \mathrm{kg}$ in North African countries to $50 € / \mathrm{kg}$ in Spanish markets, Maynou et al. 2006).

The two red shrimps constitute the main target species for the demersal deep-water fishery in the western and central Mediterranean; they are captured exclusively by trawlers on muddy bottoms, especially near submarine trenches and canyons, from 400 to $800 \mathrm{~m}$ depth. The two species are the most economically and ecologically important deep-water crustacean resource in the Mediterranean basin, together with Nephrops norvegicus (Sardà et al. 1994, Sardà et al. 2004). The distribution of Aristaeomorpha foliacea covers tropical and subtropical areas of the eastern Atlantic (including the Mediterranean) and the Indian ocean, while the distribution of Aristeus antennatus is restricted to the Mediterranean and the eastern-central Atlantic. Nevertheless, A. antennatus is eurybathic, with a documented depth of occurrence ranging from 80 to $3300 \mathrm{~m}$ (Sardà et al. 2004, and references therein), while A. foliacea has been recorded at depths ranging from 123 to 1100 m (Politou et al. 2004, and references therein). Another important feature is the longitudinal segregation of the two species along the Mediterranean: A. foliacea increases in abundance from the western to the eastern Mediterranean, while the opposite is true for A. antennatus. In Spanish Mediterranean waters, the Gulf of Lions and the Ligurian Sea A. foliacea is scarce or absent and a dominance of A. antennatus is observed (Cau et al. 2002). The abundance of $A$. foliacea increases gradually eastwards, from the Tyrrhenian Sea to the Straits of Sicily and the waters around Greece, where it becomes more abundant than A. antennatus (Cau et al. 2002). In the western Ionian Sea, A. foliacea is found in low concentrations and A. antennatus is dominant (D’Onghia et al. 1998), while in the eastern Ionian Sea the converse is true (Politou et al. 2004).

Different hypotheses have been put forward to explain the distribution pattern of the giant red shrimp A. foliacea in the Mediterranean. Different hydrological conditions (i.e. temperature and salinity) between the westernmost and the easternmost areas have been reported to affect the species distribution (Murenu et al. 1994). A. foliacea is considered to be linked to warmer and more saline water masses, such as those of the eastern Mediterranean, than A. antennatus (Ghidalia and Bourgois 1961, Cartes et al. 2011). Another major factor, which may explain its distribution pattern, is the vulnerability of the giant red shrimp to over-fishing, especially in the case of the high fishing pressure exerted on the deep waters of northwestern Mediterranean fishing grounds (D’Onghia et al. 1998). The deep waters of the western and central Mediterranean are intensively exploited down to a depth of 800 to $1000 \mathrm{~m}$, whereas they are almost unexploited in the eastern Mediterranean (waters around Greece), since commercial fishing has traditionally been carried out in waters shallower than $500 \mathrm{~m}$. In this area, A. foliacea is present in shallower waters than A. antennatus, and its main distribution range was found in the zone exploited by commercial fisheries $(<1000 \mathrm{~m})$. Also, being relatively stenobathic it has a lower resilience to changes in environmental conditions (Cartes et al. 2011). The recruitment of $A$. foliacea takes place on bottoms that can be reached by commercial trawl fleets (around $600 \mathrm{~m}$ ), which makes juveniles available to fishing. In contrast, the recruitment of $A$. antennatus takes place at unexploited depths, $1500 \mathrm{~m}$ or deeper (Sardà et al. 1994). Additionally, A. foliacea matures later than A. antennatus, with the smallest mature females being larger and older. Consequently, A. foliacea has a lower probability of reproduction before being caught in the nets and is in general more susceptible to fishing pressure (Politou et al. 2004).

Recently, it has been shown that these species have the potential to support a viable fishery in the Greek Ionian Sea (eastern Mediterranean) (Papaconstantinou and Kapiris 2001, 2003), where Aristaeomorpha foliacea is more prevalent than Aristeus antennatus. This higher abundance seems to be related to the particular ecological conditions of this area, which satisfy better the ecological demands of the giant red shrimp (Papaconstantinou and Kapiris 2003).

Red shrimps fisheries have not been historically exploited until recently in the Greek Ionian Sea because: (a) fishing at these depths yields a relatively low economic return; (b) knowledge and gear technology for fishing red shrimps is limited; and (c) red shrimps have a relative low local value, because demand for them is still limited because they have not been traditionally available in Greek fish markets and Greek consumers are not familiar with them.

From an economic point of view, the development of the red shrimp fishery in Greek waters also offers an unusual opportunity to study the market evolution of a product that is little commercialized and not familiar to the consumers, with still relatively low prices (5-6 $€ / \mathrm{kg}$ for the small fresh shrimp and 15-17 €/kg for the larger sizes). With a larger and more stable supply, it is expected that red shrimps will either create their niche in the local Greek market or be exported to other countries where they are more appreciated, resulting in an increase in ex-vessel prices. 
Considering that nearly two-thirds of assessed fish stocks worldwide may be in need of rebuilding (Worm et al. 2009), the development of sustainable new fisheries (and their markets) could become an important source of wealth generation and help to divert effort from stocks under excessive pressure. However, this may only be possible in a restricted number of cases because the precautionary principle must be applied to newly developed stocks and only $15 \%$ of worldwide marine stocks were estimated to be underexploited or moderately exploited in 2008 (FAO 2010).

Assessing the long-term sustainable potential of newly developed deep-water fisheries resources is difficult, because of the paucity of data coupled with the uncertainty of ecological and economic processes. Nonetheless, there exists a need for scientific advice to managers on the likely evolution of the fisheries resource under alternative management strategies, even when the best scientific information is simply inadequate for determining the state of exploitation (or the stock status against pre-agreed reference points: Richards and Maguire 1998, Restrepo and Powers 1999). In this context, bio-economic simulation models are a useful tool. By capturing the essential aspects of the biological and economic dynamics of a fishery, a simple bio-economic model such as the one used in this study allows scientific advice to guide the decision-making process of local fisheries managers (Larkin et al. 2011).

Here, we investigate the scope for expanding the newly developed deep shrimp trawl fishery in the eastern Ionian Sea under different management scenarios with the application of a bio-economic model. The bio-economic simulation model can also be used to analyse the effects that uncertainty in the form of future fuel price increases and changes in fish market prices may have on the profitability of the red shrimp fishery. Forecasting the biological and economic consequences of management actions before they are applied and the effects in fuel prices and market developments may help managers to select the most suitable management options.

Management options in Mediterranean fisheries are characterised by the use of restrictions on effort and technical measures. Most Mediterranean fisheries are based on effort control (i.e. limitations in the number of vessels, fishing days and hours, and closed seasons), and no quotas are implemented (except for bluefin tuna). The Mediterranean regulations have focused especially on trawl segments, which make the greatest contribution to demersal catches and have a worse selectivity pattern than more traditional artisanal segments (Lleonart and Maynou 2003).

\section{MATERIAL AND METHODS}

\section{Economic data on the deep-water shrimp fishery}

Economic data were obtained by questionnaires under the Data Collection Regulation. In particular, data

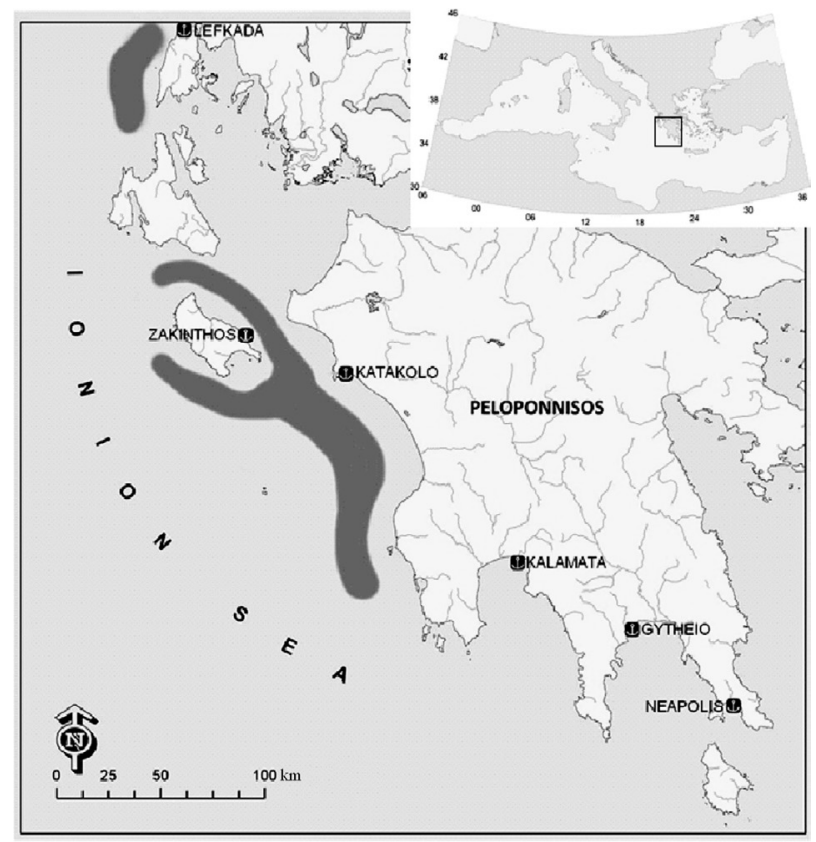

FIG. 1. - Map of the research area with the locations of the main local fishing harbours for trawlers

were collected on capacity (number of vessels, gross tonnage, engine power and average age), landings in weight and value, effort (in fishing days, kw days and gross tonnage days), employment (total employment, full-time employment, part-time employment and fulltime equivalents), revenues, costs and fuel consumption (income, crew cost, fuel cost, operational cost, capital cost, fixed cost, repair and maintenance and fuel volume consumed) and the financial position.

Deep-water shrimp fishing in Greece is mainly practiced in the west of the country (Ionian Sea) by the local trawling fleet. According to the Ministry of the Merchant Marine, there are 35 trawlers in western Greece distributed at the ports illustrated in Figure 1: Gytheio, Itea, Kalamata, Katakolo, Lefkada, Neapolis (Lakonia), Patra and Zakynthos. The main fishing grounds for red shrimps are the strait between Zakynthos and Cephalonia and the waters around the island of Zakynthos, Western Messinia and Western Lefkada (Fig. 1).

\section{The bio-economic model MEFISTO}

The bio-economic analysis was carried out using the MEFISTO 3.0 bio-economic simulation model (Lleonart et al. 1999, 2003, Maynou et al. 2006). The bio-economic model comprises a biological submodel (or stock module) and an economic submodel. The stock module simulates biological dynamics of the resource, from reproduction to growth and death, and considers two kinds of species: the main species, whose dynamics are completely known (and modelled through an age-structure biological model, such as the two red shrimp species here; see Lleonart et al. 2003 for 
the biological equations); and the secondary species, whose dynamics are not known but their contribution to total revenues is important in Mediterranean fisheries (Lleonart et al. 2003) and their catch is empirically related to the catch of the main species. Model inputs are maximum fishing effort and catchability (which are in turn the output of the economic sub-model). The product of these two kinds of species represents the fishing mortality applied to the stock. Outputs are fish catches that are converted to revenues by means of species-specific price equations.

The fish catches of each species generated by the stock model are converted into revenues through price functions. The mean price for deep-water shrimps in the local market is about $9 € / \mathrm{kg}$. Small fresh shrimp (age $\leq 2$ approximately, 50 specimens $/ \mathrm{kg}$ ) can fetch 5-6 $€ / \mathrm{kg}$ and larger sizes (age >2 approximately, 10-12 specimens $/ \mathrm{kg}$ ) can fetch $15-17 € / \mathrm{kg}$. The price function used assumed that price is independent of the amount of catches and imports, and only the effect of size (age) was modelled: $\log P=\beta 1+\beta 2 \log ($ age $)$, where $\beta 1$ and $\beta 2$ are coefficients of a linear regression between shrimp categories (small, large) and price P.

The simulations were carried out under steady-state conditions with stochastic recruitment for a projection horizon of 15 years (from 2007 onwards) using 10000 iterations. Because the simulations were carried under biological steady state and the dynamics of effort did not change over time, the trajectory of each indicator in time was very similar and only the mean and the $95 \%$ confidence interval are shown for selected indicators to facilitate comparisons across scenarios.

\section{Management strategies and simulation conditions}

With the objective of assessing the potential of the Greek fishery for red shrimp in the Ionian Sea, we established alternative scenarios based on current knowledge of this fishery and the options that fisheries managers are considering for the near future, complemented with the constraints imposed by the likely increase of fuel price in the near future. We compare the performance of selected indicators (spawning stock biomass, catches and profits) in three alternative scenarios against the current exploitation strategy (18 trawlers fishing for 2 months in the area). We also added two scenarios that explore possible changes in market conditions and fuel costs.

Scenario 1: $\mathbf{5 0 \%}$ increase in the number of days (effort) devoted to this fishery, increasing the fishing period from 2 to 3 months, for the 18 trawlers already targeting shrimps.

Scenario 2: all $\mathbf{3 5}$ trawler vessels in the area enter the red shrimp fishery in the current open season of 2 months (corresponding to a 94\% increase in capacity).

Scenario 3: The seasonal restriction is removed and the current fleet of 18 trawlers is allowed to fish shrimp during the whole year (estimated to be 267 fishing days).
TABLE 1. - Characteristics of Greek trawler vessels fishing for red shrimps. The total number of trawlers in the area is 35 .

\begin{tabular}{lc}
\hline Number of vessels & 18 \\
Average Length (m) & 24.33 \\
Average Engine power (HP) & 352.72 \\
Average Capacity (GRT) & 59.93 \\
Crew (persons/vessel) & 6.25 \\
Fishing days per vessel (days/year) & 267 \\
\hline
\end{tabular}

Scenario 4: Further, we investigated the effects of changes in market conditions that a development of the Greek market for shrimp may have on the economic performance of this trawler fleet. Development of the Greek market for shrimps would be translated into shrimp price increases, because the product in other European markets fetch higher prices: for instance in Spain ex-vessel price for A. antennatus is around $50 € /$ $\mathrm{kg}$ (Maynou et al. 2006). We compared current profitability with the scenarios of shrimp price $2 x$ and $4 \times$ current price, in line with ex-vessel prices paid in Italy or Spain (Scenarios 4.1 and 4.2).

Scenario 5: Finally, we analysed the effects that changes in fuel costs, in particular a fuel price increase, may have on the economic performance of this trawler fleet by simulating fuel price increases of $20 \%$, $50 \%$ and $100 \%$ and comparing the results with the current situation (Scenarios 5.1, 5.2 and 5.3).

\section{RESULTS}

\section{Fleet description}

From the questionnaires collected it was determined that vessels engaged in red shrimp fishing have an average length of $24.33 \mathrm{~m}$, an average engine power of $352.72 \mathrm{HP}$, and an average capacity of 59.93 GRT. They belong to the middle to high category of the Greek fleet. This would be expected because red shrimp fishing requires advanced tools and equipment (wires, gates, winches), as well as engine power (to be able to pull the net at the depths of shrimp habitat), making this fishery unsuitable for small trawlers (Maynou et al. 2006). Only 18 of the potential 35 local trawler vessels are actively engaged in red shrimp fishing at present (Table 1).

From the data collected, and presented in Anderson and Guillen (2009), it can be seen that Greek trawlers are making high profits, but revenues from red shrimps comprise a small portion of overall revenues (just 1\% of the total revenues of the fleet). Hence the fleet is not dependent exclusively on this resource, and the shrimp fishery is just an extra source of income for the trawlers that practise it.

Based on the revenues generated in the market module and the costs incurred (fuel, operational and fixed costs), the profitability of the fleet was calculated. The current economic parameters and profitability of the Greek trawl fleet operating in the Ionian Sea are shown in Table 2. 
TABle 2. - Economic performance and main cost items of Greek trawler vessels fishing for red shrimps.

\begin{tabular}{lr}
\hline Capital value of the vessel (thousand euro/vessel) & 160 \\
Annual revenues (thousand euro/vessel) & 522 \\
Annual cost (thousand euro/vessel) & 314 \\
Fuel cost (thousand euro/vessel) & 102 \\
Labour cost (thousand euro/vessel) & 63 \\
Daily cost (thousand euro/vessel) & 55 \\
Maintenance cost (thousand euro/vessel) & 35 \\
Profits (thousand euro/vessel) & 208 \\
Return on investment (\%) & 130 \\
\hline
\end{tabular}

TABLE 3. - Biological parameters for Aristeus antennatus and Aristeus antennatus for the stocks exploited by the Greek trawling fleet in the eastern Ionian Sea. Parameters of the von Bertalanffy growth function: $L_{\infty}, k$ and $t_{0}$. Parameters of the length-weight relationship: $a, b$. Natural mortality $(M)$.

\begin{tabular}{lcc}
\hline & A. foliacea & A. antennatus \\
\hline$\left.L_{\infty}(\mathrm{mm} \mathrm{CL})^{-1}\right)$ & 59.5 & 58.0 \\
$k\left(\right.$ year $\left.^{-1}\right)$ & 0.48 & 0.42 \\
$t_{0}$ (year) & -0.5 & -0.42 \\
$a$ & 0.0034 & 0.0083 \\
$b$ & 2.38 & 2.23 \\
Natural mortality (M) & 0.52 & 0.48 \\
\hline
\end{tabular}

\section{Assessment of the two red shrimp stocks}

The necessary information on the population structure at the start of the simulations regarding the number of individuals, fishing mortality $(F)$ and number of recruits $(R)$ was estimated by means of a steady-state version of Virtual Population Analysis (VPA) using the VIT program (Lleonart et al. 1999), with the biological parameters shown in Table 3 and length frequency data derived from field sampling within the EU Data Collection Framework. The initial biological conditions and fishing mortality vectors obtained through VPA analysis and used as parameters in the bio-economic model are shown in Table 4.

We carried out the analysis of alternative scenarios under the assumption of biological equilibrium, with stochastic variation of recruitment around the mean recruitment estimated through steady-state VPA. Despite extensive biological research carried out on other stocks of red shrimps in the Mediterranean in recent decades, knowledge on stock-recruitment relationships is very limited and only very short series (10 years or less) on spawning stock and recruitment exist. This data-poor situation precludes computing stock/recruitment relationships, but the existing data on variation of
TABLE 5. - Summary indicators of the base scenario (current situation).

\begin{tabular}{lccc}
\hline & A. foliacea & A. antennatus & $\begin{array}{c}\text { Eastern Ionian } \\
\text { trawl fleet }\end{array}$ \\
\hline SSB $(\mathrm{kg})$ & 21426 & 12774 & \\
catch $(\mathrm{kg})$ & 7161 & 1609 & 8770 \\
Profits $(000 €)$ & & & 3630 \\
\hline
\end{tabular}

recruitment in other Mediterranean stocks was used to establish a coefficient of variation (CV) of recruitment. We used data from Cardinale et al. (2010, p. 852 and ff) to calculate $\mathrm{CV}=0.62$ for $A$. foliace $a$ and $\mathrm{CV}=0.29$ for $A$. antennatus. In the biological model this recruitment variation was introduced as a lognormal distribution function with a mean corresponding to $N_{l}$ in Table 3 for each species and a standard deviation corresponding to sd $=$ mean $\times \mathrm{CV}$. Although the assumption of mean constant recruitment is very strong (because it implies that recruitment behaves independently of the stock level), this assumption is often used when limited data are available to calculate the stock-recruitment relationship (Silvestri and Maynou 2009).

\section{The scenarios}

\section{Scenario 0: Initial situation}

The initial scenario reflects the current situation, in which 18 trawler vessels are licensed for deep shrimp fishing during 2 months each year (corresponding to 1008 fishing-days-vessel). The summary indicators of the current situation are given in Table 5. Figures 2-4 show the values of selected indicators in the alternative scenarios compared against the current situation (Scenario 0)

\section{Scenario 1: Increase in the number of days by 50\%}

An increase of $50 \%$ in the number of days (effort) from 2 to 3 months for the 18 trawler vessels already participating in the fishery would correspond to 1512 fishing-days-vessel and was simulated by increasing the fishing mortality of each age class by $50 \%$. The simulation results show a decrease in spawning stock biomass (SSB) by $15 \%$ and $11 \%$ for A. foliacea and $A$. antennatus respectively, while catches of the two species would increase by $20 \%$ and $31 \%$, respectively, with no appreciable increase in the profits of the fleet (Figs 2-4).

TABLE 4. - Population parameters for Aristeus antennatus and Aristeus antennatus based on steady-state VPA: number of individuals at age in the reconstructed population $\left(N_{\mathrm{a}}\right)$, proportion of mature individuals at age $\left(M A T_{\mathrm{a}} a\right)$, fishing mortality at age $\left(F_{\mathrm{a}}\right)$.

\begin{tabular}{|c|c|c|c|c|c|c|c|}
\hline \multirow[b]{2}{*}{ Age (a) } & \multicolumn{3}{|c|}{ Aristaeomorpha foliacea } & \multirow[b]{2}{*}{ Age (a) } & \multicolumn{3}{|c|}{ Aristeus antennatus } \\
\hline & $\mathrm{N}_{\mathrm{a}}$ & $\mathrm{MAT}_{\mathrm{a}}$ & $\mathrm{F}_{\mathrm{a}}$ & & $\mathrm{N}_{\mathrm{a}}$ & $\mathrm{MAT}_{\mathrm{a}}$ & $\mathrm{F}_{\mathrm{a}}$ \\
\hline 1 & 1242860 & 0.121 & 0.126 & 1 & 906376 & 0.226 & 0.045 \\
\hline 2 & 651274 & 0.382 & 0.599 & 2 & 536424 & 0.567 & 0.151 \\
\hline 3 & 212728 & 0.735 & 0.554 & 3 & 285495 & 0.854 & 0.163 \\
\hline \multirow[t]{2}{*}{4} & 72687 & 0.926 & 0.1 & 4 & 150137 & 0.963 & 0.211 \\
\hline & & & & 5 & 75255 & 0.992 & 0.1 \\
\hline
\end{tabular}




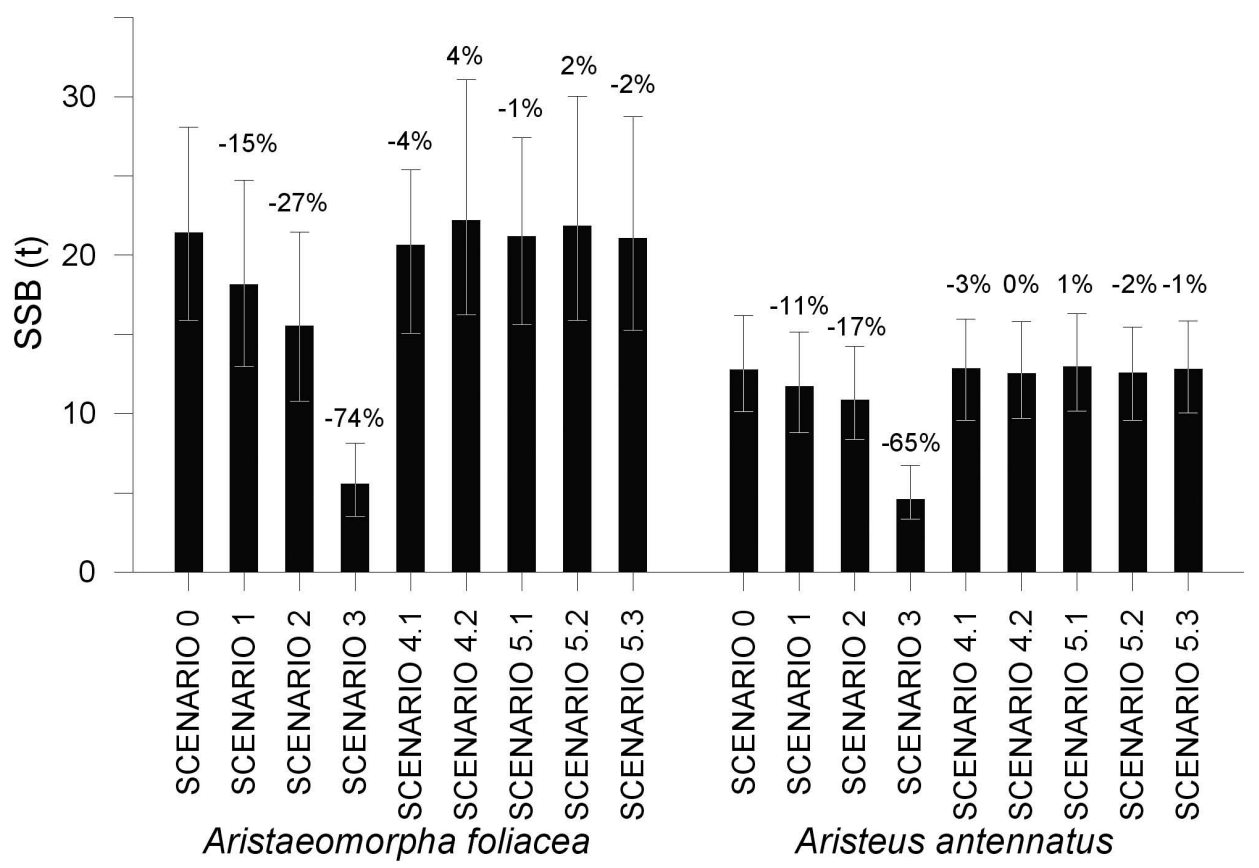

FIG. 2. - Spawning stock biomass at equilibrium under different simulation scenarios. Mean value with $95 \%$ confidence interval of 10000 simulation runs with stochastic recruitment. Values on top of the charts represent changes in percentage with relation to the current situation (2007, Scenario 0).

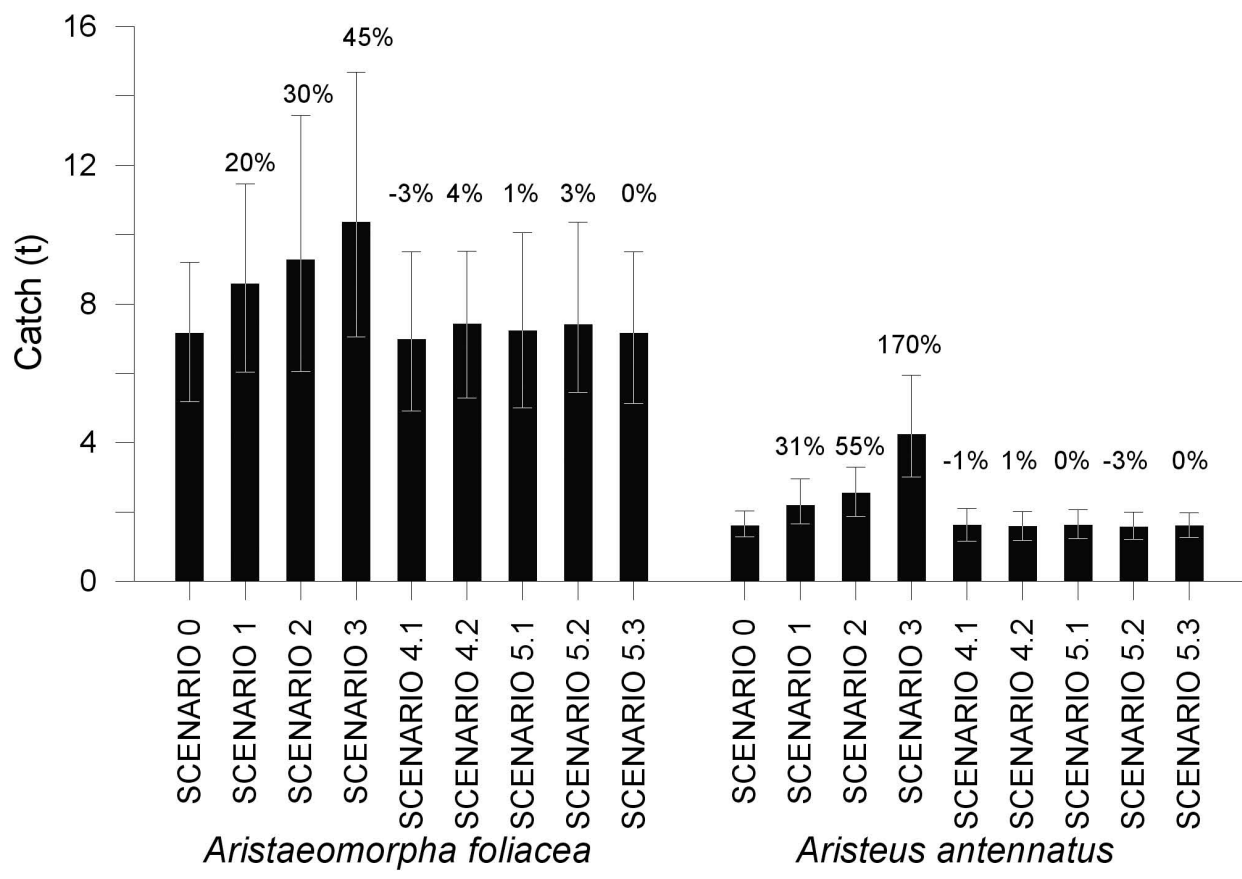

FIG. 3. - Catches at equilibrium under different simulation scenarios. Mean value with $95 \%$ confidence interval of 10000 simulation runs with stochastic recruitment. Values on top of the charts represent changes in percentage with relation to the current situation (2007, Scenario 0).

\section{Scenario 2: Increase to 35 trawlers}

An increase in the number of trawlers (capacity) from the 18 trawler vessels already participating in the fishery to the 35 vessels that operate in the area would correspond to an increase of 1960 fishing-days-vessel. This management scenario was simulated by increasing the fishing mortality of each age class by $94 \%$. The simulation results show a decrease of SSB by $27 \%$ and $17 \%$ for A. foliacea and $A$. antennatus, respectively, while catches of the two species would increase by $30 \%$ and $55 \%$, respectively, with a very small increase $(1 \%)$ in the profits of the fleet (Figs 2-4). 


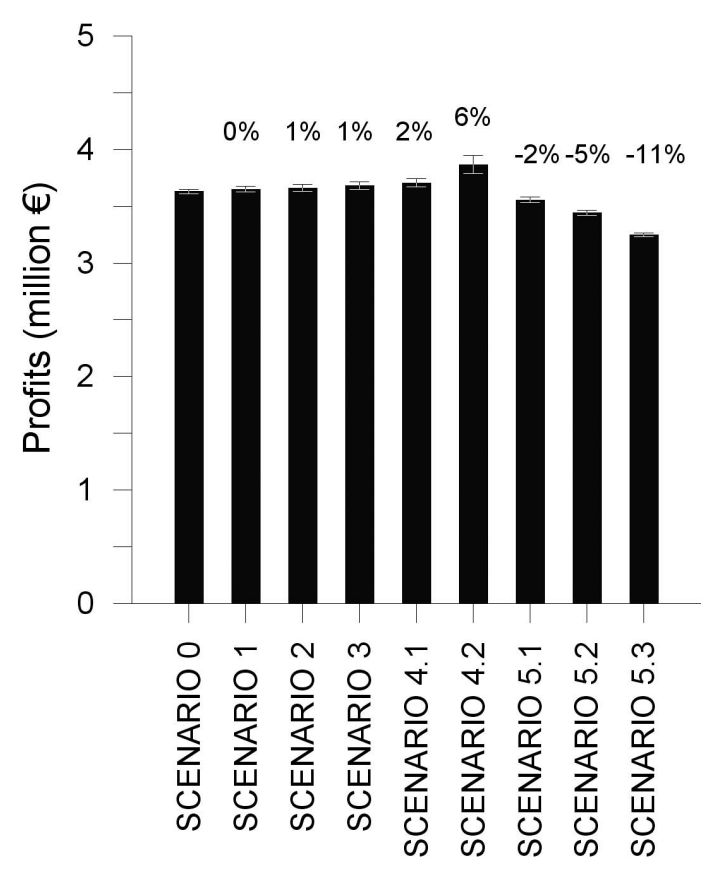

FIG. 4. - Profits at equilibrium under different simulation scenarios. Mean value with $95 \%$ confidence interval of 10000 simulation runs with stochastic recruitment. Values on top of the charts represent changes in percentage with relation to the current situation (2007, Scenario 0).

\section{Scenario 3: Fishing during the whole year}

Opening the fishery to the whole year for the 18 trawler vessels participating in the fishery corresponds to an increase of 4816 fishing-days-vessel, assuming 267 effective fishing days each year. This management scenario was simulated by increasing the fishing mortality of each age class by $477 \%$. This large increase in fishing pressure would drive the stocks of both species to very low levels: a reduction of $74 \%$ of SSB for $A$. foliacea and a reduction of $65 \%$ for A. antennatus. Under these conditions catches of $A$. foliacea would increase by $45 \%$, while catches of $A$. antennatus would increase by $170 \%$. Still, this large increase in catches (an additional $5800 \mathrm{~kg}$ ) would represent only an increase in revenues of $€ 58000$, a small fraction of the revenues of the fleet. For this reason, despite the increase in catches, profits would increase only by $1 \%$ (Figs 2-4).

\section{Scenario 4: Market development}

We analysed the effects of the development of a market for Greek red shrimps, based either on an increase of internal demand or an export market. We did this by comparing the current situation with alternative scenarios of increase in the current price by $2 x$ and $4 x$ (average of $18 € / \mathrm{kg}$ and $36 € / \mathrm{kg}$, Scenarios 4.1 and 4.2). Because these scenarios do not change the base fishing mortality (because effort is held constant), no significant effect can be expected on SSB or catches (Figs 2 and 3), but profits would increase by $2 \%$ and
$6 \%$, respectively (Fig. 4). The development of the Greek red shrimp market would allow a moderate increase in revenues and profitability of the trawler fleet, because of the small share of red shrimps in the overall annual catches.

\section{Scenario 5: Fuel price increases}

Fuel costs are the main cost in many fishing fleets, especially in trawling fleets that use active gears. In 2007, the fuel price for commercial fishers was 0.45 $€ / \mathrm{L}$ in Greece, but since 2008 global oil prices have increased and they are likely to increase in the near future. Forecasts predict that the oil price will reach 113 US\$ per barrel (in 2009 dollars) in 2035, while short-term price volatility is likely to remain high (IEA, 2010). In Scenarios 5.1, 5.2 and 5.3 fuel price increases of $20 \%, 50 \%$ and $100 \%$ relative to current prices were compared. Because these scenarios do not change the base fishing mortality, no significant effect can be expected on SSB or catches (Figs 2 and 3), but profits of the fleet would decrease by $2 \%, 5 \%$ and $11 \%$, respectively (Fig. 4)

\section{DISCUSSION}

Managing a newly developed fishery is difficult because of lack of information on many biological and economic parameters, as newly developed fisheries are typically data-poor. There are many sources of uncertainty in fisheries, but in newly developed fisheries recruitment dynamics and how the stock will respond to continued fishing pressure are particularly significant (Beddington and Cooke 1983). Here we examined alternative scenarios of the evolution of a newly developed deep-water red shrimp fishery in the eastern Ionian Sea targeting two shrimp species (Aristaeomorpha foliacea and Aristeus antennatus) that are important deep-water resources elsewhere in the Mediterranean (Sardà et al. 2004, Carlucci et al. 2006). In the absence of agreed biological reference points, it is difficult to provide managers with sound scientific advice, and providing the results of bioeconomic simulation exercises (founded on realistic alternative scenarios with assumptions clearly underlined) is a way of communicating the possibilities of expanding new fisheries to fisheries managers (Richards and Maguire 1998, Restrepo and Powers 1999). In our case, moderate increases in fishing effort (either by extending the open season by 1 month, Scenario 1, or allowing the entire local fleet entry in this fishery, Scenario 2) would allow for a moderate increase in catches (25-35\%) without jeopardizing the sustainability of the stocks (decrease of SSB from $11 \%$ to $27 \%$ on average from the base scenario). Instead, opening the fishery to the entire year (Scenario 3) would put the stocks at risk, with a reduction of 74\% of SSB in Aristaeomorpha foliacea and $65 \%$ in Aristeus antennatus. These figures show that this level of fishing pressure would 
be far from sustainable, even in the absence sufficient information to compute reference points. Furthermore, due to the relatively low price of red shrimps in the local market, a large increase in fishing effort would not increase the profits of the trawl fleet significantly. Our results show that fishing effort can slightly increase without negatively compromising the sustainability of the fishery, but would not produce significant changes in the profitability of the fleet.

The development of an internal or export red shrimp market in Greece would increase the revenues and profitability of the trawler fleet by a moderate amount (2$6 \%$ ). An increase in the demand for Greek red shrimp in the current price range analysed should not threaten the resource, because the expected benefits from targeting these species are not significant higher, so there should be no significant pressure to enter the fishery. However, this would be an incentive to increase fishing effort of the trawler fleet on deep-sea resources if shallow water resources become scarce in the future, as has happened elsewhere in the western Mediterranean (Maynou et al. 2006). If effort is increased above the thresholds previously analysed, the sustainability of the resource would be threatened.

Conversely, by increasing the exploitation costs, potential future fuel price increases (or reductions in fuel subsidies and tax exemptions, which would have the same effect since they are equivalent) may reduce the profitability of this fleet segment by $2 \%$ to $11 \%$ in the scenarios tested. Unlike fleet segments in other countries, which have been very sensitive to fuel prices changes (see for example Silvestri and Maynou 2009), this segment shows positive profits despite great fuel price increases. This is because the data for this Greek trawler fleet show a very high profitability, in accordance with the 2009 Annual Economic Report (Anderson and Guillen, 2009), which states that the economic performance of Greek fleets is not dramatically affected by fuel prices. Increases in subsidies would have the opposite effect, reducing exploitation costs and thus increasing profitability, as happened with the price increases.

Therefore, the uncertainty about the evolution of economic parameters does not significantly affect the economic performance of this fleet, as we can see from the simulations of the shrimp income and the main costs. However, more important in this fishery is the uncertainty about the biological characteristics of the resource, especially the stock-recruitment dynamics and the response of the stock to fishing effort. Though we have modelled uncertainty in the analysis and reported confidence intervals, the results should be taken as approximations.

It can be concluded from the simulations that it seems viable for the shrimp fishery to increase its effort (either by letting the 18 vessels that are currently in the fishery fish for 3 months or by letting the other 17 trawlers in the area enter the shrimp fishery for the 2 -month period). This would result in a $35 \%$ increase in the revenues from shrimps (more than $€ 50000$ per the fleet), and potentially more if a market is established. However, this effort increase should be accompanied by biological surveys to obtain precise indicators of the biomass evolution and to provide an accurate monitoring of fishing effects on particularly vulnerable deepsea habitats.

\section{ACKNOWLEDGEMENTS}

The data presented in this paper were collected during the research project "Study of the feasibility of the development of deep shrimp fishery in the Ionian Sea (Greece) and at depths lower than $500 \mathrm{~m}$ using innovative bio-economic methods and cost/benefit analysis" with reference number 176441/2006 funded by the Greek Ministry for Agricultural Development and Food. The authors also wish to thank two anonymous referees for all their positive comments. Any errors or views expressed in this paper are solely the responsibility of the authors.

\section{REFERENCES}

Anderson J., Guillen J. (Eds.) 2009. The 2009 Annual Economic Report on the European Fishing Fleet. JRC Scientific and Technical Reports. ISBN 978-92-79-14049-5.

Bas C. 2006. The Mediterranean Sea: Living resources and exploitation. CIHEAM-IAMZ / FAO COPEMED Project. Barcelona.

Beddington J.R., Cooke J. 1983. The potential yield of previously unexploited stocks. FAO Fisheries technical Paper No. 242. Food \& Agriculture Organization of the United Nations, Rome.

Cardinale M., Cheilari A., Rätz H.-J. (eds.) 2010. Assessment of Mediterranean stocks. Part I. Scientific, Technical and Economic Committee for Fisheries (STECF), JRC Scientific and Technical Reports. ISBN 978-92-79-18754-4.

Carlucci R., D’Onghia G., Sion L., Maiorano P., Tursi A. 2006. Selectivity parameters and size at first maturity in deep-water shrimps, Aristaeomorpha foliacea (Risso, 1827) and Aristeus antennatus (Risso, 1816), from the North-Western Ionian Sea (Mediterranean Sea). Hydrobiologia 557(1): 145-154.

Cartes J.E, Maynou F., Fanelli E. (2011) Nile damming as plausible cause of extinction and drop in abundance of deep-sea shrimp in the western Mediterranean over broad spatial scales. Progr. Oceanogr. 91(3): 286-294.

Cau A., Carbonell A., Follesa M.C., Mannini A., Norrito G., Orsi-Relini L., Politou C.-Y., Ragonese S., Rinelli P. 2002. MEDITS-based information on the deep-water red shrimps Aristaeomorpha foliacea and Aristeus antennatus (Crustacea: Decapoda: Aristeidae). Sci. Mar. 66(Suppl. 2): 103-124.

D’Onghia G., Mastrototaro F., Maiorano P., Basanisi M. 1998. Selectivity of the trawl net on the slope $(250-750 \mathrm{~m})$ of the Ionian Sea (Central Mediterranean Sea). Biol. Mar. Medit. 5(2): 437-448.

FAO. 2010. The state of World Fisheries and Aquaculture 2010. Food \& Agriculture Organization of the United Nations, Rome.

FAO-GFCM. 2011. Capture Production 1970-2008 database (Release date: December 2010) and FAO, 2000. FishStat Plus. Universal software for fisheries statistical time series. Version 2.3. FAO, Rome.

Ghidalia W., Bourgois F. 1961. Influence of temperature and light on the distribution of shrimps in medium and great depths. Stud. Gen. Fish. Coun. Medit. 16: 1-49.

IEA (International Energy Agency). 2010. World Energy Outlook 2010. OECD/IEA. Paris.

Larkin S.L., Alvarez S., Sylvia G., Harte M. 2011. Practical Considerations in Using Bioeconomic Modelling for Rebuilding Fisheries. OECD Food, Agriculture and Fisheries Working Papers, No. 38, OECD Publishing. http://dx.doi. org/10.1787/5kgk9qclw7mv-en. 
Lleonart J., Maynou F., Franquesa R. 1999. A bioeconomic model for Mediterranean fisheries. Fisheries Economics Newsletter 48: 1-16.

Lleonart J., Maynou F., Recasens L., Franquesa R. 2003. A bioeconomic model for Mediterranean fisheries, the hake off Catalonia (Western Mediterranean) as a case study. In: $\varnothing$. Ulltang \& G. Blom (Eds.) Fish Stock Assessments and Predictions: Integrating Relevant Knowledge. Sci. Mar. 67(Suppl. 1): 337-351.

Lleonart J., Salat J., Maynou F. 1999-2011. VIT for Windows. http:// www.mefisto.info/vit4win1_3.zip.

Maynou F., Sardà F., Tudela S., Demestre M. 2006. Management strategies for red shrimp (Aristeus antennatus) fisheries in the Catalan Sea (NW Mediterranean) based on bioeconomic simulation analysis. Aquat. Liv. Res. 19(2): 161-171.

Murenu M., Cuccu D., Follesa C., Sabatini A., Cau A. 1994. The occurrence of Aristaeomorpha foliacea in Sardinian waters. In: Bianchini M.L., Ragonese S. (eds.), Life cycles and fisheries of the deep-water red shrimps Aristaeomorpha foliacea and Aristeus antennatus. N.T.R.-I.T.P.P. Spec. Publ. 3: 49-50.

Mytilineou Ch., Kavadas S., Politou Ch.-Y., Kapiris K., Tursi A., Maiorano P. 2006. Catch Composition on Red Shrimps' (Aristaeomorpha foliacea and Aristeus antennatus) Grounds in the Eastern Ionian Sea. Hydrobiologia 557(1): 155-160.

Papaconstantinou C., Kapiris K. 2003. The biology of the giant red shrimp (Aristaeomorpha foliacea) at an unexploited fishing ground in the Greek Ionian Sea. Fish. Res. 62(1): 37-51.

Papaconstantinou C., Kapiris K. 2001. Distribution and population structure of the red shrimp (Aristeus antennatus) on an unexploited fishing ground in the Greek Ionian Sea. Aquat Liv. Res., 14(5): 303-312.

Politou Ch.-Y., Kapiris K., Maiorano P., Capezzuto F., Dokos J. 2004. Deep-sea Mediterranean biology: the case of Aristaeo- morpha foliacea (Risso, 1827) (Crustacea: Decapoda: Aristeidae). Sci. Mar. 68(Suppl. 3): 129-139.

Relini G., Orsi-Relini L. 1987. The decline of red shrimp stocks in the Gulf of Genoa. Inv. Pesq. 51(Suppl. 1): 245-260.

Restrepo V.R., Powers J. E. 1999. Precautionary control rules in US fisheries management: specification and performance. ICES J. Mar. Sci. 56: 846-852.

Richards L.J., Maguire J.-J. 1998. Recent international agreements and the precautionary approach: new directions for fisheries management science. Can. J. Fish. Aquat. Sci. 55: 1545-1552.

Sardà F., Cartes J.E., Norbis W. 1994. Spatio-temporal structure of the deep-water shrimp Aristeus antennatus (Decapoda: Aristeidae) population in the western Mediterranean. Fish. Bull. 92: 599-607.

Sardà F., D'Onghia G., Politou Ch.-Y., Company J. B., Maiorano P., Kapiris K. 2004. Deep-sea distribution, biological and ecological aspects of Aristeus antennatus (Risso, 1816) in the western and central Mediterranean Sea. Sci. Mar. 68(Suppl. 3): 117-127.

Silvestri S., Maynou F. 2009. Application of a bioeconomic model for supporting the management process of the small pelagic fishery in the Veneto Region, northern Adriatic Sea, Italy. Sci. Mar. 73(3): 563-572.

Worm B., Hilborn R., Baum J.K., Branch T.A., Collie J.S., Costello C., Fogarty M.J., Fulton E.A., Hutchings J.A., Jennings S., Jensen O.P., Lotze H.K., Mace P.M., McClanahan T.R., Minto C., Palumbi S.R., Parma A.M., Ricard D., Rosenberg A.A., Watson R., Zeller D. 2009. Rebuilding global fisheries. Science 325: 578-585.

Scient. ed.: J. Lleonart.

Received May 31, 2011. Accepted January 31, 2012

Published online May 7, 2012. 